\title{
Who Should Discuss Advance Directives With Patients With Cancer and When? A Systematic Literature Review
}

\section{Pierre Boyer}

University Department of General Practice of Toulouse

Laëtitia Gimenez ( $\square$ laetitia.gimenez@dumg-toulouse.fr)

University Department of General Practice https://orcid.org/0000-0001-7522-3995

Vladimir Druel

University Department of General Practice of Toulouse

Alicia Marcaud

University Department of General Practice of Toulouse

Marie-Eve Rougé-Bugat

University Department of General Practice of Toulouse

Research article

Keywords: Advance directives, cancer, general practitioners, oncologists

Posted Date: January 13th, 2020

DOl: https://doi.org/10.21203/rs.2.20750/v1

License: (c) (1) This work is licensed under a Creative Commons Attribution 4.0 International License. Read Full License 


\section{Abstract}

\section{Background}

Among patients with cancer, discussion about the desired care is important, because progression of the disease, particularly signs of impaired consciousness, can lead to unwanted care in situations where no advance directives (ADs) have been provided. The aim of this study was to identify the most appropriate individual and time for addressing the subject of ADs with patients with cancer.

Methods

A systematic literature review was carried out between September 2014 and August 2015, using the following databases or sets of databases: PubMed, Web of Science, Cochrane Library, EM Premium, and the French database Public Health Data Bank. The methodological aspects of the articles were selected and evaluated with the help of PRISMA international guidelines.

Results

Of the 1170 articles identified, 7 were included (6 descriptive studies, 1 interventional study). A doctor was cited as the preferred individual for discussing the subject of advance directives with the patient. In 3 studies, this was listed as a general practitioner, whereas in the other 3 studies, it was an oncologist. The most opportune time was during the absence of a serious pathology (3 studies) and at the time the disease was diagnosed (2 studies).

Conclusions

Our results support the goals of Claeys-Leonetti, a 2016 French law concerned with the rights of patients receiving end-of-life care, and they suggest the implementation of a consultation for discussing and drafting ADs.

\section{Background}

Respecting the patient's autonomy is a fundamental ethical principle in healthcare. In France, advance directives (ADs) were implemented by the Leonetti law in 2005 [1]. They make it possible for patients receiving end-of-life care with limited ability to communicate to continue to express their will.

According to the National Institute for Demographic Studies [2], 2.5\% of patients receiving end-of-life care drew up ADs in 2010. The absence of ADs can lead to unwanted aggressive medical care. According to studies by Harrington et al. [3] and Wright et al. [4], the absence of ADs was associated with poor quality of life and care of patients that also affected their relatives. Advance directives improve the psychological process in the face of death by reducing patient anxiety [5] and by providing emotional relief [6]. They help build relationships of trust $[7,8]$ and therapeutic support [9]. Advance directives reduce the stress of patients' relatives [5], lifting the burdens of difficult decisions and offering the opportunity to refocus on 
patient quality of life. For doctors, they are reassuring from both a medico-legal and decision-making perspective. Advance directives can serve as a guide and aid doctors in making difficult decisions, by informing them of the choices that patients would have made in certain situations [10]. According to Jackson et al [11], ADs reduce doctor burnout.

In France, the law known as Claeys-Leonetti [12], reaffirmed the role of ADs in 2016. An end-of-life information campaign was launched in order to encourage health professionals to discuss it with their patients. The National Authority for Health published a guide for doctors to clarify terms of use and to help them in drafting ADs [13].

However, discussion regarding ADs is often awkward. Debate and controversy with regard to the subject of ADs, particularly for patients with cancer, have been the subject of publications in scientific and medical literature for more than 20 years [14].

Only $5-25 \%$ of the population prepare ADs. This segment of the population includes both individuals in good health and those suffering from an acute, chronic, or deadly disease. These figures have changed little [9-13], despite mostly favorable attitudes toward AD arrangements [15] and information and promotion action undertaken in drafting them [16]. Likewise, we find difficulties in dialog regarding ADs, as well as an indifference among the participants on the subject of drafting them. Of the 62 patients affected by cancer who were invited to be part of a study on ADs, 29 refused to participate [17]. The majority stated a lack of interest, others mentioned fatigue or pain symptoms, and others explained that they did not want to discuss ADs. Of all those who agreed to participate in the investigation, $57 \%$ did not wish to prepare their ADs.

The barrier in communicating with the patient about ADs most cited by doctors is the fear of hurting the patient by bringing up this subject [15]. Compiling ADs requires a certain amount of caution because this questioning reminds the patient of a difficult road ahead, and it may make him or her aware too abruptly of the seriousness of his or her illness [16]. It is only to be expected that the doctor would fear creating or increasing the patient's anxiety. Answering the question about the appropriate individual and time for addressing the subject of ADs thus becomes essential.

Given the limited information in French guidelines, we have chosen to develop an inventory of the implementation of ADs among patients with cancer.

The main objective of our work was to evaluate who was the most appropriate individual to bring up the subject of $A D s$ and when, according to patients with cancer.

\section{Methods}

We carried out a systematic literature review in accordance with PRISMA (Preferred Reporting Items for Systematic reviews and Meta-Analyses) international guidelines, from September 2014 to August 2015. Bibliographical monitoring was carried out up to September 2015. 


\section{Search Strategy}

We searched the following databases or sets of databases: PubMed, Cochrane Library, Web of Science, EM Premium and the French database Public Health Data Bank. We also searched scholarly organization sites. We have also consulted the gray literature and the bibliographical references of the articles included.

The search equations should have made it possible to select articles that would help to answer the following question: "With whom and when do patients with cancer want to address the subject of advance directives?"

Each search equation was performed using English terms from the MeSH (Medical Subject Headings) database, along with (if possible) French versions of the terms, also from MeSH. The search question was itemized under 2 themes: advance directives and cancer. For advance directives: we used the English terms "advance directives" and "living wills," and we excluded the term "advance care planning." For patients with cancer, we used the terms "neoplasms" and "cancer patients." Subsequently, we performed another search, adding a third term: "communication."

MeSH definition of the descriptors:

Advance directives: "Declarations by patients, made in advance of a situation in which they may be incompetent to decide about their own care, stating their treatment preferences or authorizing a third party to make decisions for them." (Bioethics Thesaurus)

Living wills: "Written, witnessed declarations in which persons request that if they become disabled beyond reasonable expectation of retrieval, they be allowed to die rather than be kept alive by extraordinary means." (Bioethics Thesaurus)

Neoplasm: "New abnormal growth of tissue. Malignant neoplasms show a greater degree of anaplasia and have the properties of invasion and metastasis, compared to benign neoplasms." Communication: "The exchange or transmission of ideas, attitudes, or beliefs between individuals or groups."

Each MeSH term was compiled by the Boolean operator [AND].

\section{Selection Criteria: Inclusion and Exclusion Criteria}

The articles included had to be written in English or in French. The study location was not limited to any particular area. The population studied consisted of patients over 18 years of age, suffering from a cancer that is solid or of hematological origin, with no differences in the stage or evolution of the disease, and who were hospitalized or seeking inpatient or outpatient consultation. The intervention needed to involve the act of addressing the subject of ADs with the following main judgment criteria: the preferred professional, the most appropriate time to address the subject of $A D s$, or both. The article publication date should have been between January 1, 2000, and August 31, 2015.

Studies in which the population was inappropriate, the objective was unsuitable (i.e., did not involve the evaluation of the content of the ADs, the factors influencing their drafting, the method applied to improve their drafting, etc.), or the intervention did use a strict definition of advanced directives (i.e., did not discuss advanced care planning, end-of-life discussion, do-not-resuscitate orders, ethics consultation, 
etc.) were excluded. Studies for which the full text could not be retrieved were also excluded. Editorials, letters, and case analyses were not selected.

\section{Evaluation of Study Quality and Data Extraction}

Selection of the articles was carried out in several steps: reading the title, then the summary, and then the full text.

To guarantee the quality of the articles included in the literature review, we evaluated them by using the following guidelines: STROBE (STrengthening the Reporting of OBservational studies in Epidemiology) for observational studies [18] and SQUIRE (Standards for QUality Improvement Reporting Excellence) for interventional studies [19].

The analysis guide for the literature published by the National Authority for Health has also made it possible to define the items essential for the inclusion of articles and the extraction of data: precise definition of the objectives, description of the relevant context, locations and dates, definition of the eligibility criteria, definition of the sources and population selection methods, description of the data and the data collection method, description of the statistical analysis and results that can be verified using raw data.

The articles were selected by a single researcher, but they were read and analyzed by 2 researchers.

\section{Results}

\section{Selection Process}

Table 1 presents the search equations used and the number of references found in the various databases. The selection process using the databases made it possible to identify 1,170 articles, and 25 articles were identified from reading the bibliographical references in the included articles. Of the total 1,195 included articles, 26 articles were read in full, and 7 were ultimately selected (Fig. 1). 
Table 1

Databases and Search Equations Used and the Results Obtained

\begin{tabular}{|c|c|c|}
\hline Databases & Search Equations & $\begin{array}{l}\text { No. of articles } \\
\text { Found }\end{array}$ \\
\hline PubMed & $\begin{array}{l}\text { 1. Advance directives AND cancer } \\
\text { 2. ("Advance Directives"[Mesh]) AND "Neoplasms »[Mesh] } \\
\text { 3. ("Advance Directives"[Mesh]) AND "Communication"[Mesh]) } \\
\text { AND « Neoplasms "[Mesh] } \\
\text { 4. ("Living Wills"[Mesh]) AND "Neoplasms"[Mesh] }\end{array}$ & $\begin{array}{l}299 \\
155 \\
34 \\
29\end{array}$ \\
\hline Web of Science & 1. «Advance directives » AND « cancer patients » & 176 \\
\hline $\begin{array}{l}\text { Cochrane } \\
\text { Library }\end{array}$ & $\begin{array}{l}\text { 1. "advance directives" AND "cancer patients" } \\
\text { 2. Advance directives AND cancer }\end{array}$ & $\begin{array}{l}4 \\
129\end{array}$ \\
\hline EM Premium & 1. Advance directives & 367 \\
\hline $\begin{array}{l}\text { Public Health } \\
\text { Data Bank }\end{array}$ & $\begin{array}{l}\text { 1. "advance directives" AND "cancer patients" } \\
\text { 2. Advance directives AND cancer }\end{array}$ & $\begin{array}{l}3 \\
199\end{array}$ \\
\hline
\end{tabular}

\section{General Characteristics of the Included Studies (Table 2)}


Table 2

General Study Characteristics

\begin{tabular}{|c|c|c|c|c|c|}
\hline $\begin{array}{l}\text { Article Title } \\
\text { Author(s) } \\
\text { Year }\end{array}$ & Study Type & $\begin{array}{l}\text { Location } \\
\text { Duration }\end{array}$ & $\begin{array}{l}\text { Purpose of } \\
\text { the Study }\end{array}$ & Methodology & Population \\
\hline $\begin{array}{l}\text { The impact of } \\
\text { a tumor } \\
\text { diagnosis on } \\
\text { patients' } \\
\text { attitudes } \\
\text { toward } \\
\text { advance } \\
\text { directives. } \\
\text { Pfirstinger et } \\
\text { al., } 2014\end{array}$ & $\begin{array}{l}\text { Observational } \\
\text { Descriptive } \\
\text { Cross- } \\
\text { sectional } \\
\text { Unicenter }\end{array}$ & $\begin{array}{l}\text { Germany } \\
1 \text { year }\end{array}$ & $\begin{array}{l}\text { Assess } \\
\text { patients' } \\
\text { knowledge } \\
\text { of ADs, their } \\
\text { preferences } \\
\text { for a } \\
\text { discussion } \\
\text { partner and } \\
\text { the most } \\
\text { appropriate } \\
\text { time to } \\
\text { discuss } \\
\text { them after } \\
\text { diagnosis. }\end{array}$ & $\begin{array}{l}\text { Questionnaire } \\
\text { designed for the } \\
\text { study including } \\
\text { patient self- } \\
\text { assessment and } \\
\text { socio-medico- } \\
\text { demographic data } \\
\text { collection. }\end{array}$ & $\begin{array}{l}\text { Patients } \\
\text { admitted for } \\
\text { consultation in } \\
\text { the onco- } \\
\text { hematology } \\
\text { department } \\
\text { Excluded } \\
\text { patients = } \\
\text { patients with } \\
\text { bleeding } \\
\text { disorders } \\
525 \\
\text { questionnaires } \\
\text { sent } \\
\diamond 394 \text { returned } \\
\text { and analyzed } \\
\text { (response rate } \\
=75 \% \text { ) }\end{array}$ \\
\hline $\begin{array}{l}\text { Respect for } \\
\text { end-of-life } \\
\text { wishes: } \\
\text { feasibility } \\
\text { study of } \\
\text { information } \\
\text { on the trusted } \\
\text { person and } \\
\text { advance } \\
\text { directives. } \\
\text { Vinant et al., } \\
2014\end{array}$ & $\begin{array}{l}\text { Interventional } \\
\text { Prospective } \\
\text { Unicentric }\end{array}$ & $\begin{array}{l}\text { France } \\
5 \\
\text { months }\end{array}$ & $\begin{array}{l}\text { Explore the } \\
\text { feasibility for } \\
\text { patients with } \\
\text { incurable } \\
\text { cancer of an } \\
\text { information } \\
\text { intervention } \\
\text { on legal } \\
\text { devices } \\
\text { related to } \\
\text { respecting } \\
\text { the person's } \\
\text { will in } \\
\text { medical } \\
\text { decision- } \\
\text { making at } \\
\text { the end of } \\
\text { life: trusted } \\
\text { persons and } \\
\text { DAs. } \\
\text { Assess the } \\
\text { impact of } \\
\text { this } \\
\text { information } \\
\text { on patients' } \\
\text { use of these } \\
\text { devices. }\end{array}$ & $\begin{array}{l}\text { Two semi- } \\
\text { structured } \\
\text { interviews at one } \\
\text { month intervals } \\
\text { with a 4-month } \\
\text { follow-up by a } \\
\text { doctor of the } \\
\text { mobile palliative } \\
\text { care team in pairs } \\
\text { with an observing } \\
\text { nurse, following a } \\
\text { structured guide } \\
\text { combining closed } \\
\text { multiple-choice } \\
\text { questions and } \\
\text { open-ended } \\
\text { questions. } \\
\text { An accompanying } \\
\text { person could be } \\
\text { present during the } \\
\text { interviews unless } \\
\text { explicitly requested } \\
\text { by the patient. }\end{array}$ & $\begin{array}{l}\text { Patients } \\
\text { hospitalized in } \\
\text { a day hospital } \\
\text { in the } \\
\text { oncology } \\
\text { department, } \\
\text { suffering from } \\
\text { lung or } \\
\text { digestive } \\
\text { cancer } \\
\text { considered } \\
\text { incurable. } \\
103 \text { patients } \\
\text { admitted } \\
\diamond 77 \text { eligible } \\
\text { patients } \\
\diamond 23 \text { patients } \\
\text { included and } \\
1 \text { st interview } \\
\diamond 20 \text { patients } \\
2 \text { nd interview } \\
\text { performed. }\end{array}$ \\
\hline
\end{tabular}




\begin{tabular}{|c|c|c|c|c|c|}
\hline $\begin{array}{l}\text { Article Title } \\
\text { Author(s) } \\
\text { Year }\end{array}$ & Study Type & $\begin{array}{l}\text { Location } \\
\text { Duration }\end{array}$ & $\begin{array}{l}\text { Purpose of } \\
\text { the Study }\end{array}$ & Methodology & Population \\
\hline $\begin{array}{l}\text { Cancer } \\
\text { patients and } \\
\text { advance } \\
\text { directives: } \\
\text { survey of an } \\
\text { hematology } \\
\text { and oncology } \\
\text { outpatient } \\
\text { clinic } \\
\text { Hubert et al., } \\
2013\end{array}$ & $\begin{array}{l}\text { Observational } \\
\text { Descriptive } \\
\text { Cross- } \\
\text { sectional } \\
\text { Unicenter }\end{array}$ & $\begin{array}{l}\text { Germany } \\
10 \\
\text { months }\end{array}$ & $\begin{array}{l}\text { Evaluate the } \\
\text { prevalence } \\
\text { of ADs and } \\
\text { the } \\
\text { awareness } \\
\text { and attitude } \\
\text { of patients } \\
\text { toward ADs }\end{array}$ & $\begin{array}{l}\text { Standardized } \\
\text { questionnaire } \\
\text { designed } \\
\text { specifically for the } \\
\text { study, to be } \\
\text { completed } \\
\text { independently and } \\
\text { anonymously, } \\
\text { consisting of } 22 \\
\text { questions broken } \\
\text { down into } 5 \text { items }\end{array}$ & $\begin{array}{l}\text { Patients } \\
\text { admitted to } \\
\text { the onco- } \\
\text { hematology } \\
\text { department, in } \\
\text { consultation } \\
\text { or day } \\
\text { hospitalization } \\
\text { No patients } \\
\text { excluded } \\
617 \\
\text { questionnaires } \\
\text { distributed } \\
\diamond 503 \\
\text { questionnaires } \\
\text { completed and } \\
\text { returned } \\
\text { (response rate } \\
\text { of } 81.5 \% \text { ) }\end{array}$ \\
\hline $\begin{array}{l}\text { The attitudes } \\
\text { of Korean } \\
\text { cancer } \\
\text { patients, } \\
\text { family } \\
\text { caregivers, } \\
\text { oncologists, } \\
\text { and members } \\
\text { of the general } \\
\text { public toward } \\
\text { advance } \\
\text { directives } \\
\text { Keam et al., } \\
2013\end{array}$ & $\begin{array}{l}\text { Observational } \\
\text { Descriptive } \\
\text { and } \\
\text { comparative } \\
\text { Cross- } \\
\text { sectional } \\
\text { Multicenter }\end{array}$ & $\begin{array}{l}\text { South } \\
\text { Korea } \\
1 \text { year }\end{array}$ & $\begin{array}{l}\text { Examine and } \\
\text { compare the } \\
\text { attitude of } \\
\text { patients with } \\
\text { cancer, their } \\
\text { caregivers, } \\
\text { and } \\
\text { oncologists, } \\
\text { and that of } \\
\text { the public } \\
\text { toward } \\
\text { advance } \\
\text { directives } \\
\text { Identify the } \\
\text { factors } \\
\text { favorably } \\
\text { associated } \\
\text { with ADs }\end{array}$ & $\begin{array}{l}\text { Standardized } \\
\text { questionnaire } \\
\text { specially designed } \\
\text { for the study } \\
\text { consisting of } 29 \\
\text { questions divided } \\
\text { into } 3 \text { items } \\
\text { For patients, their } \\
\text { caregivers and } \\
\text { oncologists: face } \\
\text { to face interview } \\
\text { with an interviewer } \\
\text { trained in the } \\
\text { subject and the } \\
\text { questionnaire } \\
\text { For the general } \\
\text { public: telephone } \\
\text { interview with a } \\
\text { trained interviewer }\end{array}$ & $\begin{array}{l}1,242 \text { cancer } \\
\text { patients } \\
1,289 \\
\text { caregivers } \\
303 \\
\text { oncologists } \\
1,006 \\
\text { individuals } \\
\text { chosen from } \\
\text { the general } \\
\text { public }\end{array}$ \\
\hline
\end{tabular}




\begin{tabular}{|c|c|c|c|c|c|}
\hline $\begin{array}{l}\text { Article Title } \\
\text { Author(s) } \\
\text { Year }\end{array}$ & Study Type & $\begin{array}{l}\text { Location } \\
\text { Duration }\end{array}$ & $\begin{array}{l}\text { Purpose of } \\
\text { the Study }\end{array}$ & Methodology & Population \\
\hline $\begin{array}{l}\text { Advance } \\
\text { directives: } \\
\text { prevalence } \\
\text { and attitudes } \\
\text { of cancer } \\
\text { patients } \\
\text { receiving } \\
\text { radiotherapy } \\
\text { Van Oorschot } \\
\text { et al., } 2012\end{array}$ & $\begin{array}{l}\text { Observational } \\
\text { Descriptive } \\
\text { Cross- } \\
\text { sectional } \\
\text { Unicenter }\end{array}$ & $\begin{array}{l}\text { Germany } \\
39 \\
\text { months }\end{array}$ & $\begin{array}{l}\text { Examine the } \\
\text { prevalence } \\
\text { of ADs, the } \\
\text { attitude of } \\
\text { patients } \\
\text { toward ADs, } \\
\text { and the } \\
\text { factors } \\
\text { influencing } \\
\text { their drafting }\end{array}$ & $\begin{array}{l}\text { Anonymous self- } \\
\text { evaluation with a } \\
\text { standardized } \\
\text { questionnaire } \\
\text { previously used in } \\
\text { another study, } \\
\text { comprised of } 1 \\
\text { item on drafting } \\
\text { the AD itself, } 8 \\
\text { items on ADs, } \\
\text { (answers to be } \\
\text { given by the level } \\
\text { of agreement), and } \\
2 \text { items on the } \\
\text { illness and on } \\
\text { sociodemographic } \\
\text { characteristics }\end{array}$ & $\begin{array}{l}\text { Cancer } \\
\text { outpatients } \\
\text { receiving } \\
\text { radiation } \\
\text { therapy } \\
1,208 \\
\text { questionnaires } \\
\text { distributed } \\
\text { (ensuring that } \\
\text { there are no } \\
\text { duplicates) } \\
\diamond 658 \\
\text { questionnaires } \\
\text { completed and } \\
\text { returned } \\
(54.5 \%) \\
\diamond 589 \\
\text { questionnaires } \\
\text { analyzed } \\
(48.7 \%)\end{array}$ \\
\hline $\begin{array}{l}\text { Paradoxes in } \\
\text { advance care } \\
\text { planning: the } \\
\text { complex } \\
\text { relationship } \\
\text { of oncology } \\
\text { patients, their } \\
\text { physicians, } \\
\text { and advance } \\
\text { medical } \\
\text { directives } \\
\text { Dow et al., } \\
2010\end{array}$ & $\begin{array}{l}\text { Observational } \\
\text { Descriptive } \\
\text { Cross- } \\
\text { sectional } \\
\text { Unicenter }\end{array}$ & $\begin{array}{l}\text { United } \\
\text { States } \\
3 \\
\text { months }\end{array}$ & $\begin{array}{l}\text { Reevaluate } \\
\text { the } \\
\text { paradoxes } \\
\text { highlighted } \\
\text { by the } \\
\text { Lamont et al. } \\
\text { study and } \\
\text { evaluate } \\
\text { their patterns }\end{array}$ & $\begin{array}{l}\text { Semi-structured } \\
\text { interview } \\
\text { developed } \\
\text { specially for the } \\
\text { study, comprised } \\
\text { of questions from } \\
\text { the Lamont et al. } \\
\text { study; questions on } \\
\text { patient preferences } \\
\text { with respect to } \\
\text { discussion about } \\
\text { ADs and the } \\
\text { sensitivity of } \\
\text { patients toward } \\
\text { palliative care } \\
\text { It was conducted } \\
\text { by a master's } \\
\text { degree student } \\
\text { who did not } \\
\text { influence the } \\
\text { participants in their } \\
\text { questions } \\
\text { Collection of socio- } \\
\text { medical } \\
\text { demographic data } \\
\text { in the medical file. }\end{array}$ & $\begin{array}{l}\text { Cancer } \\
\text { patients } \\
\text { hospitalized in } \\
\text { the hemato- } \\
\text { oncology } \\
\text { department } \\
117 \text { patients } \\
\text { admitted } \\
\diamond 85 \text { patients } \\
\text { who received } \\
\text { an offer to } \\
\text { participate } \\
\diamond 75 \text { patients } \\
\text { participated }\end{array}$ \\
\hline
\end{tabular}




\begin{tabular}{|c|c|c|c|c|c|}
\hline $\begin{array}{l}\text { Article Title } \\
\text { Author(s) } \\
\text { Year }\end{array}$ & Study Type & $\begin{array}{l}\text { Location } \\
\text { Duration }\end{array}$ & $\begin{array}{l}\text { Purpose of } \\
\text { the Study }\end{array}$ & Methodology & Population \\
\hline $\begin{array}{l}\text { What are } \\
\text { cancer } \\
\text { patients' } \\
\text { preferences } \\
\text { about } \\
\text { treatment at } \\
\text { the end of } \\
\text { life, and who } \\
\text { should start } \\
\text { talking about } \\
\text { it? A } \\
\text { comparison } \\
\text { with healthy } \\
\text { people and } \\
\text { medical staff } \\
\text { Sahm et al., } \\
2005\end{array}$ & $\begin{array}{l}\text { Observational } \\
\text { Descriptive } \\
\text { and } \\
\text { comparative } \\
\text { Cross- } \\
\text { sectional } \\
\text { Unicenter }\end{array}$ & $\begin{array}{l}\text { Germany } \\
3 \\
\text { months }\end{array}$ & $\begin{array}{l}\text { Examine the } \\
\text { patient with } \\
\text { cancer's } \\
\text { wishes } \\
\text { concerning } \\
\text { end-of-life } \\
\text { treatment } \\
\text { and compare } \\
\text { them to } \\
\text { those of } \\
\text { individuals } \\
\text { in the control } \\
\text { group } \\
\text { (individuals } \\
\text { in good } \\
\text { health, } \\
\text { nursing } \\
\text { staff, and } \\
\text { doctors) } \\
\text { Answer the } \\
\text { following } \\
\text { questions: } \\
\text { What is } \\
\text { broadly } \\
\text { acceptable } \\
\text { in each } \\
\text { group? } \\
\text { Who should } \\
\text { take the } \\
\text { initiative in } \\
\text { addressing } \\
\text { the subject? } \\
\text { What are the } \\
\text { emotional } \\
\text { obstacles } \\
\text { that prevent } \\
\text { patients } \\
\text { from } \\
\text { completing } \\
\text { ADs? }\end{array}$ & $\begin{array}{l}\text { Standardized } \\
\text { questionnaire } \\
\text { designed } \\
\text { specifically for the } \\
\text { study, completed } \\
\text { anonymously, } \\
\text { consisted of } 29 \\
\text { questions } \\
\text { Collection of socio- } \\
\text { demographic data }\end{array}$ & $\begin{array}{l}\text { Patients } \\
\text { recently } \\
\text { diagnosed or } \\
\text { with advanced } \\
\text { cancer, treated } \\
\text { at the } \\
\text { Oncological } \\
\text { Clinic and } \\
\text { Breast Cancer } \\
\text { Center } \\
100 \text { patients } \\
100 \\
\text { individuals in } \\
\text { good health } \\
100 \text { nurses } \\
100 \text { doctors }\end{array}$ \\
\hline
\end{tabular}

Of the 7 studies included, 6 were cross-sectional observational, and 1 was interventional. The most represented country was Germany, with 4 articles. We also included 1 French article, 1 American article, and 1 South Korean article. One study was from 2005, and 6 were published between 2010 and 2015. The duration of the studies varied from 3 months to 1 year. The patient samples studied included 23 to 1,242 patients. The average age of the patents ranged from 51 to 64 (where it was indicated). In 5 articles, the patients came from outpatient or day hospital consultations. One article was about hospitalized patients, and one article did not specify the source of the patients. Both hematological and solid tumor cancers and all stages of cancer were included. 
With regard to methodology, 5 studies followed a quantitative method, 4 used specifically designed standardized questionnaires, and 1 study used a previously established questionnaire. Finally, 2 studies followed a qualitative method using semi-structured interviews; for the first one, a guide designed specifically for the study was followed, and for the other one, a guide derived from a previous study with added questions was followed.

\section{With Whom Should Patients With Cancer Discuss ADs?}

Six out of the seven articles included in this literature review provide answers to this question.

(1) Doctors

The 2 types of specialists most often mentioned as those who should address ADs with patients with cancer were the general practitioner and the oncologist. In 2 studies, the general practitioner was the most mentioned.

In a study by Pfistinger et al. [17], 231 out of 285 patients without ADs answered the item "preference for the consulting partner" (a multiple-choice question); 71\% (163/231) chose the general practitioner (of which, $82 \%$ [133/163] chose the general practitioner exclusively [a single answer]), and 26\% (60/231) chose the oncologist/hematologist (of which, 53\% [32/60] exclusively).

A study by Hubert et al. [20] provides further information. In response to the question "who is your source of information about ADs?" (with several possible answers), $61 \%$ of patients with ADs (vs. $74 \%$ patients without ADs) chose the general practitioner, and $58.5 \%$ of patients with ADs (vs. $42.6 \%$ of patients without ADs) chose the hospital practitioner. For the question "who to choose to assist in their drafting?" (with multiple answers possible), $22.3 \%$ of patients with ADs chose the general practitioner, and $3.8 \%$ chose the hospital practitioner/specialist. Moreover, in response to the question "who is the knowledgeable individual when it comes to drafting your ADs?" (with multiple answers possible), 40.8\% of patients with $A D$ s chose the general practitioner, and $14 \%$ chose the hospital practitioner/specialist.

A study by Dow et al. [21] placed the oncologist in first place. When the 75 patients participating in the study were asked directly about whom they would prefer to discuss ADs, 48\% (36/75) responded that they preferred the oncologist, and $34 \%(26 / 75)$ responded that they preferred the attending physician. It should be noted that $3 \%(2 / 75)$ chose their surgeon. This result is in line with a study by Vinant et al. [22] in which 2 out of 20 patients indicated that they preferred that this information be delivered by their oncologist. Likewise, in a study by Sahm et al. [23], to the question "who should initiate the discussion about drafting ADs?" $60.2 \%$ of patients answered "YES" to the suggestion of "the doctors," and $39.8 \%$ answered “NO” ( $\mathrm{n}=98)$.

Alongside these data, the studies by Dow et al. [21] and Vinant et al. [22] have highlighted that some patients would prefer that the doctor who addresses the subject of ADs not be directly involved in the patient's care. In the study by Dow et al. [21], when 75 patients were asked directly, "with whom would the 
patient prefer to discuss ADs?" $11 \%(8 / 75)$ chose the doctor who admitted the patient to the hospital. Of these same 75 patients, $87 \%$ (65/75) approved of the policy that the doctor admitting the patient to the hospital could discuss ADs with the patient during the admission process. Of the 70 patients included in the study who had not discussed ADs with their oncologist, 77\% (54/70) did not want to have this discussion with their oncologist. However, ironically, of those patients, $87 \%(47 / 54)$ approved of the idea that the doctor admitting the patient to the hospital could discuss ADs with the patient during the admission process. Likewise, in the study by Vinant et al. [22], several individuals agreed that the professional required to give information about ADs should not be involved in his or her care. In contrast, in the study by Sahm et al. [23], in response to the question "who should initiate the discussion about drafting ADs?" regarding a doctor's suggestion as a routine policy, $27 \%$ of respondents answered "YES" and $72.9 \%$ answered "NO" $(n=96)$.

It should be noted that, in the study by Hubert et al. [20], of the 412 patients with whom the oncologist did not discuss ADs, 52\% (215/412) wanted the doctor to address this subject. In the study by Dow et al. [21], only $23 \%(16 / 70)$ of 70 patients that did not discuss ADs with the oncologist, wanted him or her to do so. In the study by Vinant et al. [22], some patients insisted that the professional prove their competence with regard to legal provisions and in the communication field. Finally, in the study by Dow et al. [21], when 75 patients were asked (in an open question) their reason for choosing a specific doctor (among the answer choices), 24\% (18/75) believed that it was the doctor who knew the patient the best, $24 \%$ (18/75) believed that the doctor was the most practical person to choose or the person with whom they had the most interaction, 21\% (16/75) believed that it was the doctor who had the most knowledge with regard to the evolution of their disease, $16 \%(12 / 75)$ believed that it was the doctor who had good presence, $9 \%(7 / 75)$ did not give a reason, and $5 \%(4 / 75)$ provided another reason.

(2) Patients' relatives

This group of individuals was examined in only 2 studies. In the study by Hubert et al. [20], they were mentioned as individuals who were eligible to provide assistance in the drafting of ADs by $40.1 \%$ (first place) of patients who had issued ADs, whereas 93\% (first place) mentioned them as knowledgeable individuals when it comes to drafting ADs. In the study by Sahm et al. [23], when patients were asked to answer whether their relatives should initiate the discussion of the drafting of the ADs, $44.2 \%$ of patients answered "YES" and 55.7\% answered "NO" $(n=95)$. It should be noted that, in the study by Dow et al. [21], out of the 54 patients who did not want to discuss ADs with their oncologist, $22 \%$ believe that it was more of a family or personal decision.

(3) Legal professionals

Legal professionals were considered in 3 studies.

In the study by Pfistinger et al. [17], of the 285 patients without ADs, 8\% (19/285) wanted to obtain legal advice. In a study by Van Oorschot et al. [24], for the item "the directives must be certified by a notary," the 139 patients with an AD predominantly disagreed or strongly disagreed; the 314 patients without ADs but 
who were likely to obtain them in the future predominantly disagreed, and the 53 patients without an AD and who were unlikely to obtain them in the future predominantly disagreed or agreed. Finally, individuals in the notary/lawyer category were mentioned among those who should provide assistance in the drafting of ADs (25.5\%) in the study by Hubert et al. [20].

(4) Other type of individuals

In 2 studies, 2 other types of individuals were considered: the clergyperson and the psychologist. In the study by Hubert et al. [20], for $3 \%$ of patients without an AD, a pastor is mentioned as a source of information. In the study by Sahm et al. [23], in response to the question "who would initiate the discussion about drafting ADs?" $11.5 \%$ of patients answered "YES" to the suggestion of "the clergy or psychologists," and $88.4 \%$ answered "NO" ( $n=95)$. Finally, in the study by Hubert et al. [20], with regard to the information source, the media is mentioned by $22 \%$ of patients with ADs and by $19.6 \%$ of patients without ADs.

\section{When Is the Best Time to Discuss ADs With Patients With Cancer?}

Four out of the seven articles included in this literature review provide answers to this question.

(1) During a state of "good health"

In 3 out of 4 studies, patients suggested that the most opportune time to address the subject of ADs was prior to the disease, "when one is in good health." Vinant et al. [22] reported that out of 20 patients who evaluated the time for information about advance directives, 11 patients answered "in good health." This finding is in agreement with those of the study by Pfistinger et al. [17], in which, out of 285 patients without ADs, 47\% (135/285) believed that this discussion should take place independently of the neoplastic disease. In a South Korean study by Keam et al. [25], in a state of good health was the third most preferred time; of the 1,242 patients, $17.6 \%(217 / 1,242)$ believed that the drafting of ADs should take place while the patient was in good health. These findings were in line with those of the study by Sahm et al. [23], in which, in response to the question of "who should initiate the discussion about drafting ADs?", for "only affected individuals," $81.6 \%(n=98)$ of respondents answered "NO" and $18.3 \%$ answered "YES."

(2) During the diagnosis

In the study by Pfistinger et al. [17], during the diagnosis was the third most preferred time; $12 \%(33 / 285)$ of patients without ADs chose "after the cancer diagnosis news." In the study by Keam et al. [25], during the diagnosis was the second most preferred time, chosen by $29.5 \%(364 / 1,242)$ of oncology patients. In the case of the study by Vinant et al. [22], 9 patients out of 20 suggested that the time of information about ADs take place "at the outset of the treatment for a serious illness."

(3) During palliative status

Page 13/20 
Keam et al. [25] reported that $37.2 \%(459 / 1,242)$ of patients, which was the majority, in their study believed that this discussion should take place during terminal status, and $15.7 \%(193 / 1,242)$ believed it should take place when death was imminent. During "incurable disease" status was the least preferred time in the study by Pfistinger et al. [17]; only 9\% (25/285) of patients in the study chose this option. Likewise, "when the treatments for the disease are no longer enough" and "upon reaching the end of life" were not chosen by patients in the study by Vinant et al. [22]. Of note, in the study by Pfistinger et al. [17], "when the patient requests it" was chosen by $33 \%$ of patients without an AD (93/285).

\section{Discussion}

Our literature review demonstrated that a doctor, particularly a general practitioner or an oncologist, is the individual with which patients prefer to discuss the subject of ADs. The most appropriate times were when patients were in good health (before the appearance of a serious pathology) and at the time of the disease's diagnosis.

We limited our search to publications from the year 2000 onward in order to study the most recent data. We focused on the most recent data because the field is constantly evolving, along with the ethical, medical, and legislative issues involved. The first observation that we can make is that the subject of drafting $A D s$ and, more broadly, end-of-life medical conditions, is universal. However, legislative progress regarding the end of life is not the same on all continents.

The main limitation of our study is due to a selection bias because, despite the articles being read and analyzed by two researchers, there was only a single researcher in place to select and evaluate the articles. However, the inclusion of articles from various countries and various cultures makes it possible to gain broader external validity.

\section{With Which Professional Do Patients Want to Discuss ADs?}

Our study finds that the doctors who would most likely be chosen by patients are oncologists and general practitioners. Palliative care doctors, nurses, and legal professionals were not cited or evaluated.

The American study by Dow et al. [21] showed that patients would allow this discussion to occur during the admission process. The question could then be addressed when opening an outpatient medical file or upon hospitalization, for example. This form of standardization would make it possible to prevent associating ADs with an imminent end-of-life scenario. This hypothesis is supported by the French study by Vinant et al. [22], where patients wanted the doctor addressing the subject of ADs to not be involved in the medical care.

Moreover, the importance of the general practitioner should be pointed out; the general practitioner was the most preferred professional in 2 studies and the second most preferred professional in a third study. This can be explained by the fact that, as a primary care physician, the general practitioner knows the 
patient the best, from a medical and personal point of view, and for the longest amount of time. He or she is the "patient care coordinator" [26]. He or she is often the family doctor who knows the patient's sociofamily context and could initiate the discussion on ADs with the patient and his or her family during a home or medical office consultation.

O'Sullivan et al. [27] found that patients who consider the subject of ADs extremely important prefer that their family doctor be the individual to initiate the discussion.

\section{When Is the Right Time to Address the Subject of ADs?}

For patients, various times were identified: apart from a serious pathology, when the patient is in "good health," (from 3 studies).

This raises the question of the validity of ADs and the variation in choices over time. In 2007, Haas et al. [8] confirmed that the view of patients can vary widely upon approaching end of life; it is not fixed, and evolves, as Aubry had already suggested in 2006 [28]. Priorities change as death approaches. Are the wishes of an individual in good health the same as those of a sick individual? Also, how does one anticipate the medical consequences and possible treatments for a disease that one does not have?

In 2 studies, the "time of diagnosis" was identified as being the most appropriate time. However, this time, in particular in the context of cancer, already requires several explanations: the diagnosis itself, the therapeutic strategy, and access to support care [29]. A Swiss study from 2014 [30] reported similar types of answers from the point of view of the general practitioner. This study was conducted with 23 general practitioners of various nationalities (Italian, German, French, and Swiss) and its main objective was the evaluation of the "right" time to discuss ADs. Three trends in the answers emerged: "when the individual is in good health," "when he/she is still in good health but has a serious or chronic illness," and "systematically upon the first consultation, during a life event or when entering a retirement home."

This also raises the question of the patient's competence and medical knowledge [31] (i.e. whether and when to decide what is best for him or her). How would an individual who does not know the possible evolution of his or her illness or the technical care required be in a position to make decisions about his or her medical care? However, it is also the ability to make clear judgements and to be able to give consent, which, for example, raises the question of the value to be placed upon a request to cease medical care that is made by a depressed patient. How do you distinguish, in the case of a request to cease medical care, how much is due to a lucid and legitimate desire, how much is due to depression that can be treated with therapy, and how much is due to fatigue associated with the treatment? In Report N ${ }^{\circ} 58$ of the National Consultative Ethics Committee [32], the following is stated: "the act of consenting implies a dual capacity: that of being able to understand and that of being able to freely determine."

This also raises the problem of patient information and therefore the time to be granted to them for drafting ADs. A study conducted in Geneva in 2008 [33], evaluated the time necessary for the drafting of advance directives for patients assisted by 2 nurses. The average length of time required was 3.2 hours. 
In France, the Claeys-Leonetti law was passed in February 2016. It specifies the procedures for drafting ADs and the appointment of the support person and confirms the role of the primary care physician with regard to the information and the reporting thereof. The National Authority for Health published documents for health professionals and patients in order to spread awareness of ADs and to direct their drafting $[13,34]$. In the document aimed at health professionals regarding the question of "When?" the answers were in line with our results: "among individuals that do not currently have a serious illness," "among individuals who have a serious illness," and "among individuals who are fragile or vulnerable." The document provides information on how to address the subject of ADs (including listening, information, explanations, and exchanges). In the United States, the American Academy Family Physicians prepared a guide [35] for family doctors in order to increase the use of ADs. This guide offers various approaches depending on the patient's health status.

Even if our literature review and the new French law provide the types of answers that promote the drafting of ADs, certain barriers still exist, such as the training of general practitioners regarding ADs and the actual time that must be dedicated to the discussion and preparation of ADs.

\section{Conclusions}

We have carried out a systematic literature review in order to determine the professional with which patients with cancer prefer to discuss ADs and when they would prefer to have this discussion. We have highlighted, at the end of this work, that the most appropriate times were when patients were in good health (before the appearance of a serious pathology) and at the time of diagnosis. The preferred professional was a doctor, in particular a general practitioner or an oncologist. We believe it would be worthwhile to suggest a consultation dedicated to drafting ADs, whether outpatient or inpatient. Our results resonate with the 2016 French law concerning the rights of patients receiving end-of-life care, but they also indicate that health professionals need to dedicate time to this issue.

\section{List Of Abreviations}

ADs: Advanced Directives

\section{Declarations}

\section{- Ethics approval and consent to participate}

Not applicable

- Consent for publication

Not applicable

- Availability of data and material 
Not applicable

\section{- Competing interests}

The authors declare that they have no competing interests.

\section{- Funding}

No source of funding is to be reported for this study.

\section{- Authors' contributions}

PB and AM : study conception , formal analyse, writing manuscript preparation (AM : visualization/data presentation) (PB : methodology, computation, writing the initial draft).

LG : writing manuscript, critical review, commentary and revision

VD : critical review, commentary and revision

MERB : critical review, supervision.

All authors read and approved the final manuscript.

\section{- Acknowledgements}

The authors would like to thank Professor Hervé Maisonneuve for his friendly contribution

\section{References}

1. Loi $n^{\circ} 2005-370$ du 22 avril 2005 relative aux droits des malades et à la fin de vie In Journal officiel de la République française. 23 rd April. Paris; 2005:7089.

2. Pennec, A. Monnier, S. Pontone, R. Aubry. End-of-life medical decisions in France: a death certificate follow-up survey 5years after the 2005 Act of parliament on Patients' rights and End of life. BMC Palliat Care, 2012, 11 (1), p. 25

3. Harrington SE, Smith TJ. The role of chemotherapy at the end of life: "When is enough, enough?" JAMA, 2008, 299:2667-2678.

4. Wright AA, Zhang B, Ray A, et al. Associations between EOL discussions, patient mental health, medical care near death, and caregiver bereavement adjustment. JAMA, 2008, 300:1665-167

5. Detering KM, Hancock AD, Reade MC, Silvester W. The impact of advance care planning on end of life care in elderly patients: randomised controlled trial. BMJ 2010, 340:c1345

6. Jaquiéry M, Le Lous P, Paillet D. Mes dernières volontés... Soins infirmiers, 2004, p46-49.

7. Anwar D, Corbaz P, Mazzocato C, David S, Hurst S. L'éthique dans le contexte des soins palliatifs, Extraits du Guide des soins palliatifs du médecin vaudois no 11, 2009. Revue internationale de soins 
palliatifs. 2010, 25(3):133.

8. Haas S, Guédon E, Joly C, Déchelotte P. Directives anticipées : quels enjeux éthiques et quelles recommandations pratiques ? Éthique \& Santé. déc 2007, 4(4):218-224.

9. Forest MI. Rédiger les directives anticipées, pour ne vivre sous l'emprise d'aucun autre...? JALMAV. 2005, (83):16-24.

10. Civard-Racinais A. Fin de vie : faut-il changer la loi? Panorama du médecin. 2008, 5107, p12-19.

11. Jackson VA, Mack J, Matsuyama R, Lakoma MD, Sullivan AM, Arnold RM, Weeks JC, Block SD: A qualitative study of oncologists' approaches to end-of-life care. J Palliat Med 2008,11:893-906.

12. LOI n 2016-87 du 2 février 2016 créant de nouveaux droits en faveur des malades et des personnes en fin de vie.

13. Haute Autorité de Santé. Les directives anticipées - Document destiné aux professionnels de santé et du secteur médico-social et social [Internet]. 2016 avr. Disponible sur: https://www.hassante.fr/upload/docs/application/pdf/2016-03/da_professionnels_v11_actualisation.pdf

14. Ewer MS, Taubert JK. Advance directives in the intensive care unit of a tertiary cancer center. 1 oct 1995;76(7):1268-74.

15. Ellenberg E. Communication et fin de vie: revue bibliographique et approche éthique de la caresse. InfoKara 2004, 19(2):59.

16. Pérotin V. Tout ce que vous vouliez savoir sur la loi Léonetti. Médecine Palliative : Soins de Support Accompagnement - Éthique. juin 2012, 11(3):148-157.

17. Pfirstinger $J$, Kattner $D$, Edinger $M$, Andreesen $R$, Vogelhuber $M$ : The impact of a tumor diagnosis on patients' attitudes toward advance directives. Oncology 2014;87:246-256.

18. von Elm E, Altman DG, Egger M, Pocock SJ, Gøtzsche PC, Vandenbroucke JP, et al. The Strengthening the Reporting of Observational Studies in Epidemiology (STROBE) statement: guidelines for reporting observational studies. Prev Med. oct 2007;45(4):247-

19. Davidoff F, Batalden P, Stevens D, Ogrinc G, Mooney S, SQUIRE Development Group. Publication guidelines for quality improvement in health care: evolution of the SQUIRE project. Qual Saf Health Care. oct 2008;17 Suppl 1:i3-9.

20. Hubert E, Schulte N, Belle S, Gerhardt A, Merx K, Hofmann W-K, Stein A, Burkholder I, Hofheinz R-D, Kripp M : Cancer patients and advance directives : a survey of patients in a hematology and oncology outpatient clinic. Onkologie 2013;36:398-402.

21. Dow L, Matsuyama R, Ramakrishman V, Kuhn L, Lamont E, Lyckholm L, Smith T. Paradoxes in advance care planning : the complex relationship of oncology patients, their physicians, and advance medical directives. J Clin Oncol 2010;28:299-304.

22. Vinant P, Rousseau I, Huillard O, Goldwasser F, Guillard M-Y, Colombet I. Respect des volontés en fin de vie : étude de faisabilité d'une information sur la personne de confiance et les directives anticipées. Bull Cancer 2015;102:234-244. 
23. Sahm S, Will R, Hommel G : What are cancer patients' preferences about treatment at the end of life, and who should start talking about it? A comparison with healthy people and medical staff. Support Care cancer 2005;13:206-214.

24. van Oorschot B, Schuler M, Simon A, Flentje M : Advance directives : prevalence and attitudes of cancer patients receiving radiotherapy 2012;20:2729-2736.

25. Keam B, Yun Y, Heo D, Park B, Cho C-H : The attitudes of korean cancer patients, family caregivers, oncologits, and members of the general public toward advance directives 2013;21:1437-1444.

26. LOI n 2016-41 du 26 janvier 2016 de modernisation de notre système de santé - Article 68. 2016-41 janv 26, 2016.

27. O'Sullivan R, Mailo K, Angeles R et al, Advance directives : survey of primary care patients. Canadian Family Physician 2015;61:353-6

28. Aubry R. [Effects of the Leonetti Law in terms of responsibility and confidence]. Soins Gerontol. déc 2006;(62):39-41.

29. Rouge-Bugat M-E, Lassoued D, Bacrie J, Boussier N, Delord J-P, Oustric S, et al. Guideline sheets on the side effects of anticancer drugs are useful for general practitioners. Support Care Cancer Off $\mathrm{J}$ Multinatl Assoc Support Care Cancer. déc 2015;23(12):3473-

30. Otte I-C, Jung C, Elger B : Advance directives and the impact of timing : a quality study with Swiss general practionners. Swiss Med Wkly. 2014;144:w14035

31. Forest MI. Rédiger les directives anticipées, pour ne vivre sous l'emprise d'aucun autre...? JALMAV. 2005;(83):16-24.

32. Consentement éclairé et information des personnes qui se prêtent à des actes de soin ou de recherche [Internet]. Comité Consultatif National d'Ethique; 1998 juin. Report No.: 58. Disponible sur: https://www.ccne-ethique.fr/sites/default/files/publications/avis058.pdf

33. Jaquiéry M, Le Lous P, Paillet D. Mes dernières volontés... Soins infirmiers. 2004;46-49.

34. Les directives anticipées concernant les situations de fin de vie - Guide pour le grand public [Internet]. Haute Autorité de Santé; 2016 oct. Disponible sur: https://www.hassante.fr/upload/docs/application/pdf/2016-

03/directives_anticipees_concernant_les_situations_de_fin_de_vie_v16.pdf

35. Spoelhof G, Elliott B, Implementing advance directives in office practice. Am Fam Physician. 2012;85(5):461-466.

\section{Figures}


Articles identified in database search $(n=1170)$

- from PubMed ( $\mathrm{n}=299)$

- from Web of Science $(n=176)$

- from Cochrane Library $(n=129)$

- from Public Health Data Bank ( $n=199)$

Articles identified in a manual search from bibliographic references $(n=25)$

Articles excluded based on the title and/or summary $(\mathrm{n}=1$ 169)

Articles selected after reading the title and/or summary

$(\mathrm{n}=26)$

An article selected based on the summary but could not be retrieved in its entirety

Articles read in their entirety which were excluded $(\mathrm{n}=18)$

Articles selected after a full reading and evaluation $(n=7)$

\section{Figure 1}

Flow chart of systematic literature review procedure

\section{Supplementary Files}

This is a list of supplementary files associated with this preprint. Click to download.

- PRISMA2009checklistBMCPalliativecarereviewADs.doc 